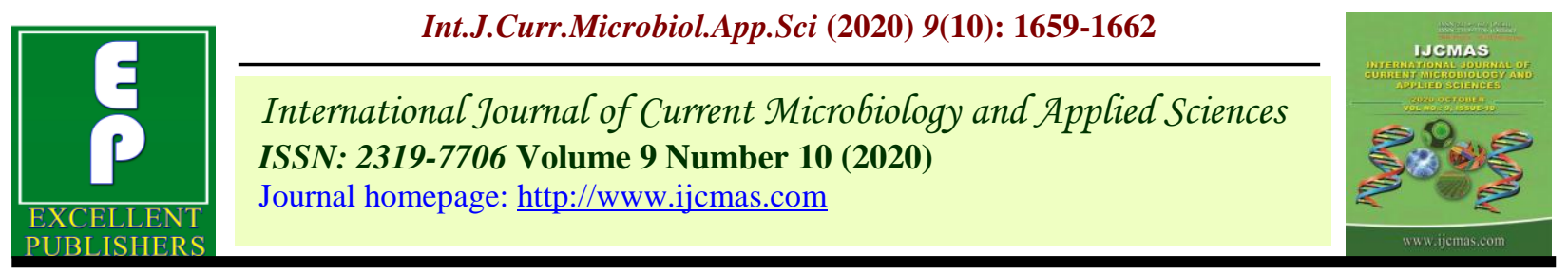

Original Research Article

https://doi.org/10.20546/ijcmas.2020.910.200

\title{
Evaluation of Nest Box Management on Hatching Egg Hygiene and Chick Quality
}

\author{
C. Ramani, G. Raj Manohar ${ }^{*}$, D. Ilaya Bharathi and P. Selvan \\ College of Poultry Production and Management, Hosur, Tamil Nadu Veterinary and Animal \\ Sciences University, India \\ *Corresponding author
}

\section{A B S T R A C T}

\section{Keywords}

Egg Fumigation, Nest box management, Chick quality

\section{Article Info}

Accepted:

15 September 2020 Available Online: 10 October 2020
The study was carried out to investigate the effect of hatching egg fumigation and nest box management on egg hygiene and chick quality. Eggs collected from two randomly selected farms were fumigated in the farm itself. Egg shell impression was made on selective agar plates before and after fumigation to study the shell microbial load from nest box. After that the eggs were hatched following standard incubation protocol and chick quality was evaluated based on chick length, body weight, vent temperature, chick yield, yolk free body mass and chick grading. The results showed that proper nest box management resulted in reduced microbial load on the egg shell and improved chick quality.

\section{Introduction}

The success of a breeder flock depends on producing good quality hatching eggs with high hatchability and delivering first quality chicks. Hatching egg hygiene is influenced by nest material, nest box management, health status, environmental temperature and the bird's feed or nutrient intake. Under natural conditions, avian eggs are equipped with a diverse microflora of commensal strains but still contamination of hatching eggs with more pathogenic bacteria species may cause poor hatchability and decreased chick performance in industrial broiler production (Baxter-Jones, 1991; Wang et al., 2011).

Most eggshell contamination occurs immediately after eggs are laid and the main source of contamination of hatching eggs is contact of shells with dirty surfaces (Dolman and Board, 1992). Therefore, the location and sanitation of the place of oviposition is critical in relation to obtaining hatching eggs with minimum contamination of the eggshells (Sparks and Board, 1985). However, in large 
scale production, the presence of some dirty eggs is almost inevitable, and particular attention to sufficient disinfection must be given to visibly dirty eggs, otherwise they may carry a high load of bacteria into the hatcher which may result in low hatchability and high mortality of the chicks (Buhr et al., 2015).

\section{Materials and Methods}

\section{Bacterial sampling of surface of eggshells}

Eggshell samples were obtained at two different time points for 3 consecutive days (Table 1). 50 eggs per day from two farms chosen and sampled before and after fumigation at the laying farm and then stored in egg cold room at $17-19^{\circ} \mathrm{C}$. Fumigation was done using a mixture of $50 \mathrm{ml}$ perox and 2450 $\mathrm{ml}$ of water. The temperature and the relative humidity in the fumigation chamber were kept between 24 to $38^{\circ} \mathrm{C}$ and 60 to $80 \%$, respectively.

With a gloved hand, the broad end of the egg surface only stamped (Egg impression method) on the Tryptic Soy Agar (TSA) plates. For a single plate four eggs surface samples were taken. Immediately after taking sample, plates are sent to the laboratory for incubation.

\section{Chick quality measurements}

Chick length, Body weight, Vent temperature, Chick yield, Yolk free body mass, Chick grading were determined.

\section{Chick length}

Length of chicks has been measured in $\mathrm{mm}$ with the help of chick measuring scale. To determine chick length, the chick was laid on its ventral side, with the neck and right leg extended to their maximum length. Chick length was defined as the length from the tip of the beak to the middle toe.

\section{Chick weight}

The chick weight was measured with an electronic balance to the nearest $0.1 \mathrm{~g}$ accuracy. Body weight is measured by weighing the whole chick. To calculate an average body weight of the population, approximately 15 chicks need to be weighed.

\section{Vent temperature}

Chick comfort can be determined by measuring chick vent temperature using a medical ear thermometer. The optimum chick vent temperature is $103-105^{\circ} \mathrm{F}$.

\section{Chick yield}

Chick yield (the weight of the chick at hatch as a percentage of egg setting weight) is a simple method of checking whether hatch timing and incubation parameters are correct.

$67-68 \%$ is the ideal chick yield.

$$
\begin{aligned}
& \text { Average Chick weight } \\
& \% \text { Chick yield }=\underset{\text { Average fresh egg weight }}{-} \times 100
\end{aligned}
$$

\section{Yolk free body mass}

Fifteen chicks per flock were euthanized humanely and weighed. The entire yolk sac from the body cavity was then carefully removed and weighed individually. Calculate the yolk sac to body weight ratio by using the following formula. Acceptable yolk sac to body weight percentage is $11 \%$ or less.

Weight of Yolk sac
Yolk free body mass =
Weight of Chick




\section{Results and Discussion}

\section{Hatching egg hygiene}

Total viable count before and after fumigation on the surface of the egg shell microbial load in the farm where nest box is closed (F1) at night and farm in which nest box is open at night (F2) for 3 consecutive days are depicted in Table 1. On all the days F1 showed lower microbial load compared to F2.

Table.1 Total viable count on the broad end of egg shell before and after fumigation (log cfu per broad end of egg)

\begin{tabular}{|c|l|c|c|}
\hline \multicolumn{2}{|c|}{ Total viable count } & Before Fumigation & After Fumigation \\
\hline \multirow{2}{*}{ Day 1 } & Closed NB (F1) & 1.32 & 0.85 \\
\cline { 2 - 4 } Day 2 & Open NB (F2) & 1.38 & 1.15 \\
\cline { 2 - 4 } & Closed NB (F1) & 1.34 & 0.85 \\
\hline \multirow{2}{*}{ Opay 3 } & Closed NB (F2) & 1.40 & 1.16 \\
\cline { 2 - 4 } & Open NB (F2) & 1.27 & 0.85 \\
\hline
\end{tabular}

Table.2 Chick length $(\mathrm{cm})$, Chick weight $(\mathrm{g})$ and Vent temperature $(\mathrm{F})$ Chick yield, Yolk free body mass (\%) and Chick grades

\begin{tabular}{|l|c|c|}
\hline \multicolumn{1}{|c|}{ Parameters } & Closed NB (F1) & Open NB (F2) \\
\hline Chick length $(\mathbf{c m})$ & 20.2 & 19.8 \\
\hline Chick weight $(\mathbf{g})$ & 48 & 47.9 \\
\hline Vent temperature( $\left.{ }^{\circ} \mathbf{F}\right)$ & 48 & 47.9 \\
\hline Chick yield $(\boldsymbol{\%})$ & 66.5 & 66.8 \\
\hline Yolk free body mass (\%) & 10.44 & 9.91 \\
\hline Black buttons & 2 & 2 \\
\hline Strings & 1 & 4 \\
\hline Sticky & 1 & 3 \\
\hline Red hocks & - & 1 \\
\hline
\end{tabular}

\section{Chick quality measurements}

Analysis of chick quality shows that good nest box management positively influences on the chick quality as shown in the Table 2 . Chick length, chick weight, vent temperature, Chick yield and yolk free body mass (\%) in farm 1 showed positive correlation with egg shell microbial quality.

The influence of egg shell contamination from nest boxes in farm 2 resulted in lower chick length $(20.02 \mathrm{~cm})$ compared to chick length in farm $2(19.8 \mathrm{~cm})$. The same trend was followed in other parameters such as chick weight, vent temperature, Chick yield and yolk free body mass (\%) as well.

The presented data shows the importance of nest box management on the egg hygiene and chick quality. The chick quality expressed as chick weight, chick length, vent temperature, chick yield and yolk free body mass as the most important parameters shows better results when simple nest management is followed in the farm. Nest box hygiene is 
very important when considering hatching egg hygiene and chick quality. A dirty nest box or site will result in increased embryo mortality. So the study recommends ensuring that closing nest boxes at night time from access to the laying hen will provide good quality chicks compared to the chicks from farms where nest boxes are open to layers at night.

\section{References}

Baxter-Jones C. Egg hygiene: microbial contamination, significance and control. Avian Incubation, Poult. Sci. Symp., 22 (1991), pp. 269-275.

Buhr R.J., J.S. Mauldin, S. Bailey, N.A. Cox. Automated spray sanitizing of broiler hatching egg. J. Appl. Poult. Res., 3 (2015), pp. 226-233.

Dolman J., R.G. Board. The influence of temperature on the behaviour of mixed bacterial contamination of the shell membrane of the hen's egg. Epidemiol. Infect., 108 (1992), pp. 115-121.

Sparks N.H., R.G. Board. Bacterial penetration of the recently oviposited shell of hens' eggs. Aust. Vet. J., 62 (1985), pp. 169-170.

Wang J.M., M.K. Firestone, S.R. Beissinger. Microbial and environmental effects on avian egg viability: do tropical mechanisms act in a temperate environment? Ecology., 92 (2011), pp. 1137-1145.

\section{How to cite this article:}

Ramani, C., G. Raj Manohar, D. Ilaya Bharathi and Selvan, P. 2020. Evaluation of Nest Box Management on Hatching Egg Hygiene and Chick Quality. Int.J.Curr.Microbiol.App.Sci. 9(10): 1659-1662. doi: https://doi.org/10.20546/ijcmas.2020.910.200 